\title{
Accuracy of Words Rigidity in Prabowo Subianto's Political Communication
}

\author{
Ermanto $^{1 *}$, David Syasli², Novia Juita ${ }^{3}$
}

\author{
${ }^{1 *}$ State University of Padang, Jl. Prof. Dr. Hamka Padang. 25131. Indonesia, ermanto@fbs.unp.ac.id \\ ${ }^{2}$ State University of Padang, Jl. Prof. Dr. Hamka Padang. 25131. Indonesia, $\square$ david.syasli999@gmail.com \\ ${ }^{3}$ State University of Padang, Jl. Prof. Dr. Hamka Padang. 25131. Indonesia, $\triangle$ noviajuita@ymail.com
}

\begin{abstract}
Accuracy of standard and non-standard words a figure presenting these figures competency in utilizing Indonesian while conveying ideas, opinions, and valuation of an object. Prabowo is a politician who utilize the standard and not as a means to achieve political objectives. The method used in this study the descriptive method with qualitative approach. The data collection technique is a technique capable refer engaged free through downloading data from www.youtube.com; Gerindra TV, transcribed for analysis. The results showed the use of standard words $98.91 \%$ and $1.09 \%$ non-standard words. The word comes from the standard no foreign language and regional languages potentially understood by all citizens of Indonesia, to be given Indonesian equivalent word right, good, and true.
\end{abstract}

Keywords: accuracy, words, communication, political

\section{INTRODUCTION}

In KBBI accuracy means coincidentally; exactness; precision [1]. Accuracy of diction is an attempt to present the accuracy, precision, or the accuracy of word choice in communication activities. According Keraf [2] diction is choice of words or diction is much wider than what is reflected by the relationship of those words. This term is used to describe not only which words are used to express an idea or ideas, but also includes phraseology, style and expression. Irfariati [3] argued that in communication required options or diction appropriate words to get the message or information to be conveyed can be received correctly and effectively.

Word choice support businesses in achieving the purpose of communicating. The more choices the easier words to express their opinions, ideas, judgments and criticism in communication quality. Latifah [4] stated that the quality of one's language depends on the quantity of its vocabulary, the richer vocabulary possessed it will be greater the skilled person's ability to speak. Sulistyaningtyas [5] suggests that word selected must be able to provide the precision of meaning because in certain communities often have a meaning of a word is good, and the other people give meaning less good. Appropriate selection of words related to politeness. Opinion Ermanto [6] that the communication performance of politicians in terms of politeness and civility in political approach uses the principle of modesty guided by the adage wisdom, generosity, praise, humility, approval and sympathy.

The use of language in a formal state will pay attention to word choice, either standard or non-standard words. Setiawati [7] found Indonesian dictionary is one of learning resources that can be used in learning basic vocabulary and non-standard, According Defina [8] required attention in the use of standard and non-standard words to fit with the intent and purpose of communication.

Political figures take advantage of the language with a choice of standard and non-standard words in campaign activities. Said an official communication standard supports the viewing of political figures. Words could not standard to demonstrate competencies intentional or unintentional due to the negligence of the political leaders. The word comes from the standard is not a foreign language or dialect has not been received within KBBI. Opinion Jamilah [9] that things need to be considered is the form of the absorption of foreign words, incorrect word usage situation, cutting words, and words redundant. Hardianto [10] states that kata-words and style of language used in advertising campaigns to attract listeners / sympathy of society to realize the idea of nationality.

One Indonesian political figures are interesting to be accurate kestandardan choice of words is Prabowo. Prabowo many appearances in communicating political program. In this study were taken four official speech Prabowo uploaded in [11] www.youtube.com; gerindra.tv. Faisal [12] states Indonesian speakers, especially among the educated and the bureaucrats, should follow the guidelines for the use of standard Indonesian. So the problem in this research is how kestandardan said an official speech when a presidential candidate Prabowo 2019-2024 period. The purpose of this study is to obtain analytical results standard said an official speech as a presidential candidate Prabowo 2019-2024 period. 
Standard variety is the kind of language used in formal or official situations. The rules in the standard variety is usually used consistently expressed in [13]. Arifin and Tasai [14] also revealed that the standard variety is the diversity of languages institutionalized and recognized by citizens most of its user community as the official language and frame of reference of language norms in use. In the standard Indonesian grammar [15]. explained that the standard language is a variety of language education that have dynamic stability properties in the form of rules and regulations are fixed, have kencedikiaan properties are realized in sentences, paragraphs, and units of another language that expresses logical reasoning, and has a uniformity of nature rules. Additionally, Sumarsono and Pertana [16] also revealed that the standard variety refers to the kind of language that was appreciated by the wearer's quality is higher than other varieties. Arifin and Tasai [14] also argued that the standard language spoken is the standard language used orally with no accent or dialect includes the effect of a particular area. Meanwhile, according Sumarsono and Partana [16], the standard variety of oral less volatile arena certainly difficult to determine the point in the pronunciation. Based on the issues raised can be stated that the standard language written and spoken is a wide standard variety used officially in accordance with the guidelines Indonesian spelling enhanced and without accentuate the influence of certain regional dialects.

In the Indonesian language, the standard variety was only one, the language in accordance with standard Indonesian grammar and spelling guidelines Indonesian enhanced. This is in accordance with the opinion of Sumarsono and Partana [16] that the difference in the standard language and standard not involve all the components of language, namely tatabunyi, order forms, vocabulary, and syntax. Errors in the use of the language component is often called a wide variety of language the language is not standardized. This opinion is also in line with what is proposed by Santoso [17] that the non-standard sentence is a sentence of the form does not meet a requirement as a sentence, while in terms of its contents are not to be a means of communication is perfect. Sentences that are not standard can also be sentences that are not effective, not normative, and illogical. Based on those opinions can be stated that the diversity of languages is not standard is the kind of language that is incompatible with the sound system, system formation, and syntax Indonesian standard language.

Based on the description above this researchanalyze the accuracy of the use of standard and non-standard words of political speech Prabowo dated January 14, 2019, August 10, 2018, September 21, 2018, and October 30, 2018 broadcast live by CNN Indonesia [18]. Prabowo is the subject of research and the use of standard and non-standard words in an official speech by Prabowo became the object of this study.

\section{METHOD}

This research is qualitative research with descriptive method. Qualitative research is an activity that takes place simultaneously with the activities of the data analysis by describing the problem-solving methods oblek studied [19]. Collecting of the data refer to the free Engaged method capable. Sudaryanto [20] argued see or listening method is a research method where the obtained data is done by listening to the use of language. The research data is a speech Prabowodate January 14, 2019, August 10, 2018, September 21, 2018, and October 30, 2018. The data source is a verbal speech recordings obtained from Youtube Prabowo Gerindra Tv [11]. The data analysis technique is to identify the data that determine the accuracy of the use of standard and non standard word Prabowo.

\section{RESULTS AND DISCUSSION}

Research result

Based on the results of data collected as many as 4975 words, gained as much as 54 words are not standard or $1: 09 \%$ and 4,921 or $98.91 \%$ of standard words with reference to [1] KBBI compiled by Sugono [21]. Said standard predominately used for oral communication Prabowo Prabowo is done in the form of an official speech. Prabowo choose words based on the rules that have been determined and constant rule, possess kencedikiaan embodied in sentences, paragraphs, and that of other language that expresses logical reasoning, as well as possess the uniformity of the rules until the words are in accordance with the rules and spelling rules of Indonesian and in accordance with standard language resources that Big Indonesian Dictionary (KBBI) [1]

The word is not standard is derived from foreign languages and dialects. The use of the word is not standard of a foreign language helps speakers using a clear reference in their assessments and opinions on the phenomenon raised. The use of the word is not standard of regional languages show speakers have an understanding of local knowledge is good and wise, and have a high sense of nationalism. The following table analyzes the results of calculations using standard and non standard word Prabowo.

Table 1 Use of The Word Standard / Not Standard Prabowo

\begin{tabular}{|c|c|c|c|}
\hline $\begin{array}{c}\text { Num } \\
\text { ber }\end{array}$ & $\begin{array}{c}\text { Standard / Not } \\
\text { standard }\end{array}$ & $\begin{array}{c}\text { The } \\
\text { Amount of } \\
\text { Data }\end{array}$ & Percentage \\
\hline 1 & Standard & 4921 & $98.91 \%$ \\
\hline 2 & Not standard & 54 & $1.09 \%$ \\
\hline & Total & 4975 & $100 \%$ \\
\hline
\end{tabular}

The use of the word is not standard in Prabowo's oral communication just as much as $1.09 \%$. This small amount can have a great usability. Speakers include the word standard is not influenced by foreign languages as a 
reference views towards an idea. Some words are not standard found can be categorized as code-mixing, because the word is not standard is the word pronunciation or writing is not in accordance with the rules which standardized the guidelines spelling (EYD), grammar standard and common dictionary [22] to intervene insert as code as the use of the word is not standard. The following examples are not standard words derived from foreign languages:

(1) Hukum Thucydides mengatakan: The strong will do what they can, the weak suffer what they must, jadi kalau dalam bahasa Indonesia, yang kuat akan berbuat apa yang dia mampu buat, yang lemah akan menderita apa yang dia harus derita. (CNN Indonesia) [18]

(2) Bukan seperti sekarang, pakar-pakar ekonomi mengatakan, sekarang sedang terjadi deindustrialisasi di Indonesia. (CNN Indonesia) [18]

(3) Kami akan berjuang untuk sediakan susu gratis, dan makan siang gratis di setiap sekolah yang membutuhkan, kami harapkan akan kurangi stunting. (CNN Indonesia) [18]

(4) Kami juga akan tingkatkan kemampuan kepolisian agar mampu mengantisipasi dan mengatasi kejahatan-kejahatan baru seperti cyber-crime, human trafficking, international drug trafficking, pencucian uang, dan lain sebagainya. (CNN Indonesia) [18]

(5) Agar sebuah bangsa dapat merdeka, berdaulat, makmur dan menang, bangsa itu harus melalui proses nation building yang dicapai dari sebuah proses pembangunan karakter, character building. (CNN Indonesia) [18]

(6) The best and the brightest sons and daughters of Indonesia. (CNN Indonesia) [18]

In the speech (1) above the speaker deliberately use some foreign quotations are not in accordance with the rules of Indonesian dictionary and code-mixing categorized according Thealander opinion in Chaer [23], which is codemixing the said event, clause -klausa and phrases used consisted of a mixture of clauses and phrases, and each clause, phrase no longer support its own function. Foreign language speech Prabowo is a direct quote figures opinion translated into Indonesian namely; 'yang kuat akan berbuat apa yang dia mampu buat, yang lemah akan menderita apa yang dia harus derita'. Deliberate quoting this phrase accompanied translated show Prabowo would like to remind that in any case the Indonesian nation must become a strong nation, otherwise it will be a weak nation and will be oppressed because of weakness.

In the speech (2) intentionally used for the word deindustrialization speakers representing speakers assessment of the conditions to be he responded. The term deindustrialization, used in accordance with the rules specified Indonesian, deindustrialisation meaning is the opposite of industrialization [24]. Deindutrialisasi synonym of 'opposed to industrialization' should be given Prabowo listener so that people understand the meaning.
In the speech (3) said stunting started familiar in public communication Indonesia but not in accordance with the rules of Indonesian because it comes from the English language meaning 'pengkerdilan' [25]. The term is also significant stunting of children growing conditions are not normal due to poor nutrition. The use of this term intentionally done Prabowo because he wanted to reveal the internal state of the thoughts and feelings about the development of children from economically weak families. Matching the right word is 'malnutrition' and need to be addressed to make it easier to understand the general public.

In the speech (4) the speaker deliberately use the word cyber-crime, human trafficking, international drug trafficking, the foreign terms that means 'kejahatan dunia maya, perdagangan manusia, perdagangan narkoba internasional' [25]. Matching foreign terms may be presented in accordance meaning to the general understanding of the listener more leverage. According to Yuliana [26] use a foreign term for it is international and prevalent by experts in their field and get into Indonesian for a more subtle connotations, the word is shorter than it's translated, and is international rather than a counterpart.

In the speech (5) speakers intentionally used the word nation building, character building, the foreign terms that means 'pembangunan nasional, pembentukan karakter' [25]. Matching foreign terms can also be presented in accordance meaning derived from the translation to make it easier to understand the general public.

In the speech (6) speakers intentionally use the phrase The best and the brightest sons and daughters of Indonesia, is a foreign phrase which means 'putra dan putri terbaik dan terpandai di Indonesia' [25]. This sentence can be served in the Indonesian language as a whole to the understanding of ordinary people deeper and stronger. This sentence is also categorized according the opinion Thealander code-mixing [23].

User word standard is not derived from the local language there is deliberate speaker in support of the idea or the reference has put forward the concept of the ideal. Local knowledge into persuasive media for the listener because it shows the interest and ability of speakers on thought patterns like the wise elders who recognizes a growing conditions. Example;

(7) Sikap sabdo pandito ratu yang selalu tepat ucapan. (CNN Indonesia) [18]

(8) Sikap rame ing gaweh, sepi ing pamrih yang mendahulukan kepentingan yang besar. (CNN Indonesia) [18]

(9) Sikap pemimpin bekerja agar wong cilik iso gumuyu. (CNN Indonesia) [18

(10) Seorang gubernur yang bekerja keras untuk rakyat, untuk petani, untuk nelayan, untuk wong cilik di seluruh Jawa Tengah. (CNN Indonesia) [18]

In the speech (7) is deliberately used speakers because the queen is said Sabdo Pandito Java terms means 'perkataan penguasa / raja suci' [27], The phrase is a way of life which is owned by the previous Java, which emphasizes the great value that the true personality looking 
ahead and tend to be cautious in the act, it could put the object, subject, place and the right time. It takes the narrative equivalent term for the Indonesian people who are not of Javanese do not understand the purpose of these terms.

In the speech (8) also deliberately used the term rame ing gaweh, sepi ing pamrih is the philosophy of the Java community, which means 'banyak dalam kerja, tanpa mengharapkan imbalan' [27], The concept of spoken Javanese philosophy Prabowo according to Javanese culture should embrace and run and cling in any work, especially by the leader to be a picture of an exemplary leader. The term is also not understood by the people of Indonesia are not of Javanese and require precise equivalent word.

In the speech (9) deliberately spoken since the term "wong cilik iso gumuyu", the terms Java, which means 'rakyat kecil bisa tertawa', This expression conveyed Prabowo Prabowo aspire for the welfare of the Indonesian people completely. The speech also need a synonym to be understood by the people of Indonesia completely.

In the speech (10) speakers wong cilik use the word, because it is a Java terms, which means 'rakyat kecil' [27], This term is used to describe the social classes in traditional Javanese society similar to "ordinary people" in a feudal society. People who are not ethnic Javanese less understand the term, which would require the equivalent word to describe it.

In addition to the use of the word standard is not intentional, also found the use of the word standard is not accidental. The cause of this usage because the speaker forget and do not yet have a standard equivalent to the words used. Examples of non-standard words inadvertently used.

(11) Bagi Saudara-saudara yang bertaruh nyawa di jalanan sebagai pekerja angkutan, kami akan berikan kepastian hukum untuk para pengemudi ojol, pengemudi taksi, pengemudi bis, dan tentukan tarif minimal yang menguntungkan pekerja dan pengusaha. (CNN Indonesia) [18]

(12) Dengan program-program yang tepat sasaran seperti beasiswa atlet, beasiswa santri, dan transportasi gratis untuk pelajar, manula dan kaum disabilitas, kami akan pastikan jarak antara orang kaya dan orang miskin tidak semakin lebar. (CNN Indonesia) [18]

(13) Tapi kalau saya nggak nakal, nggak jadi jenderal. (CNN Indonesia) [18]

In the speech (11) above "ojol" spoken since the term began to familiar in Indonesian society. Ojol words used are not in accordance with the rules of Indonesian and could be replaced with a motorcycle taxi motorcycle taxi online means based systems in the Internet network [21]. Motorcycle in the Internet network development is very rapid. The development is inseparable from the pros and cons. Support for motorcycle through the Internet for a new job and the practical benefits for users of freight transport services and shipping. Denials came as concerns groups who do not want to follow the development of the Internet network for transportation and delivery or traditional motorcycle group who did not want to turn to the internet network. Because the term ojol already familiar, then to mediate and dstandard support from both transportation model in this traditional networks and Prabowo use these terms as well as lifting the discourse of welfare improvement for providers of transport services. This means that the speaker has not come across the term substitutes ojol exact terms.

In the speech (12) is spoken for "manula" already familiar term in the community of Jakarta. Said manula who use not in accordance with the rules of Indonesian can be replaced by 'tua renta or lansia'. Lansia is an acronym of lanjut usia. The term manula or "elderly man" is a term that actually strange because in terms of seniors contained a discrimination and harassment of a community of people who should get a place of honor which are words that show they are the people our parents were very instrumental to our existence. Prabowo said the term is involuntarily due to not quite understand the word acronym seniors. For those who understand the risk of dropping the appearance of Prabowo because it sounded abusive language.

In the speech (13) inadvertently not spoken since the word "nggak" is a word familiar to the citizens of Jakarta. In the dictionary of words nggak discuss Java means no [27], Environmental factors are familiar using the word does not make Prabowo no attention to the use of this word nggak as observers appearance Prabowo understand the intent of the word. Changes speaking style that originally appeared with a formalized, structured and regular shifts into a more familiar speech leads to a relaxed style for speaking about his best friend to affect formality Prabowo speaking styles. The use of the word nggak considered so influential, in fact Prabowo know the exact synonym for the word 'no', but felt not need to be corrected.

\section{Discussion}

Prabowo wear standard word for a word in accordance with the rules of Indonesian. The rules of the benchmark is the standard word Spelling Indonesian General Guidelines (PUEBI) and its use refers to the Big Indonesian Dictionary (KBBI). Standard word often used in the phrase deliberately formal conversation or speech nuanced by Prabowo campaign for committing verbal communication with people who are respected, admired, and is expected to give full support to him in the electoral process in 2019.

Opinion Waridah [28], the function of the standard words in Indonesian is: 1) Uniting; Prabowo Indonesian utilize as a unifying language, especially in uniting the ideas, views, judgment, and wisdom of the condition of the state and nation. By bringing together these ideas prabowo explicitly ask for the support to become president or win the presidential election in 2019. The narrative Prabowo peculiarities of dialects unites every region in Indonesia through the Indonesian standard, so that each region was an integral part of the Indonesian nation intact. 2) Giving distinctiveness; the use of a standard language may be characteristic for Prabowo. Prabowo utilizing standard language in his speeches, to be presented differentiator means speaking with other presidential candidates. 3) 
Carrier Authority; the use of words can be carriers of standard authority for its speakers. A speaker who uses the standard words in his speech will be considered as being the authoritative and worthy of respect. This is because the standard language is identical to the formality and politeness. Prabowo use standard language shows as a speaker who understands and upholds the Indonesian language is good and true. Therefore, the use of standard Indonesian can improve Prabowo authority. 4) Terms of Reference; Prabowo standard language used to be a reference citizen of the Republic of Indonesia in the language. This is because the standard language is the language in accordance with the rules of Indonesian, so it deserves to be the reference language. Prabowo is able to use standard language well, until Prabowo considered competent use of the Indonesian language is good and true.

The use of the word standard is not deliberate and Prabowo there is no unintentional. Deliberate use of the word is not standard code-mixing can be categorized as Prabowo deliver sentences, terms, and words of a foreign language and the local language as a strong reference to the ideas put forward. The reference clearly shows Prabowo has the competence and wisdom in presenting ideas and views. The use of the word standard is not accidental very little, this is because Prabowo not have the right words to convey the equivalent of the term, and there is a term that is very familiar to the Indonesian people but it is a language that is not acceptable in the area PUEBI or KBBI.

In comparison of this research is the study Agustin [29] which suggests the results of research that President Soeharto more use of diction abstract, diction particular, diction denotatif, and diction popular, then stained the use of diction regional and diction typical, and in terms of style dominated by stylistic repetition and stylistic parallelism to highlight a word or group of words the same function, but if overused make sentences in a speech to be stiffer. While this study focuses more standard dominant use of the word and the word is not standard also affects the public's understanding of Indonesia to the intent or the finer points in political communication Prabowo.

\section{CONCLUSION}

This research obtains conclusions based on the results of data analysis and discussion of the use of standard words in the official campaign speech, Prabowo so dominant that as many as 4,921 words or $98.91 \%$, while use of the word standard is not only 54 words or $1.09 \%$. The use of standard word used by Prabowo has been appropriate and in accordance with the rules and regulations are fixed, have critism properties are realized in sentences, paragraphs, and other units of language that expresses logical reasoning, and has a uniformity of nature rules. Utilization of non-standard words deep need attention so that all Indonesian people who watched the speech can understand the intent of the official speeches Prabowo Indonesia entirety and society do not lose important points are presented as choice of words derived from foreign languages and dialects. Matching the right words to represent the non-standard words derived from foreign languages and regional languages should be given to the understanding of the people of Indonesia from Sabang to Merauke equal and maximum.

\section{REFERENCES}

[1] KBBI. 2016. Kamus Besar Bahasa Indonesia (KBBI). [Online] Available at: http://kbbi.kemdikbud.go.id/entri/akurasi [Diakses 9 September 2019]

[2] Keraf, Gorys. 2004. Diksi dan Gaya Bahasa. Jakarta: PT Gramedia Pustaka Utama.

[3] Irfariati. 2013. Diksi Dalam Retorika Anas Urbaningrum, Madah, Volume 4, Nomor 1, Edisi April, pp. 11-24

[4] Latifah, Chori, dan Muhammad Rohmadi, Edy Suryanto. 2016. Penggunaan Diksi Dalam Karangan Berita Siswa Sekolah Menengah Pertama, BASASTRA Jurnal Penelitian Bahasa, Sastra Indonesia dan Pengajarannya Volume 4 Nomor 1, April, ISSN I2302-6405, pp. 84-101

[5] Sulistyaningtyas, Tri. 2008. Diksi dalam Wacana Iklan Berbahasa Indonesia; Satu Kajian Sosiopragmatik, , Jurnal Sosioteknologi Edisi 15 Tahun 7, Desember, pp. 495-503.

[6] Ermanto, Agustina, and Emidar. 2018. Forms Of Violation Of Politeness In Communicating Local Political Figures In West Sumatra: Riview of International Conference on Language, Literature, and Education (ICLLE 2018) Advances in Social Science, Education and Humanities Research, volume 263

[7] Setiawati, Sulis. 2016. Penggunaan Kamus Besar Bahasa Indonesia (KBBI) dalam Pembelajaran Kosakata Baku Dan Tidak Baku Pada Siswa Kelas IV SD, Jurnal Gramatika Jurnal Penelitian Bahasa dan Sastra Indonesia V2.i1 pp. 44-51.

[8] Defina. 2014. Pemakaian Kata Tidak Baku dikarenakan dalam Abstrak Karya Ilmiah (Studi Kasus Karya Ilmiah di garuda.dikti.go.id), Miangun Jurnal Ilmiah Kabahasaan dan Kesastraan Volume 7, Nomor 7 Juni, pp. 35-45.

[9] Jamilah. 2017. Penggunaan Bahasa Baku Dalam Karya Ilmiah Mahasiswa, Jurnal Tarbiyah (Jurnal Ilmiah Kependidikan) Vol. 6 No. 2. Juli Desember, pp. 41-51.

[10] Hardianto, Musa, Wahyu Widayati, Sucipto. (2017). Diksi Dan Gaya Bahasa Pada Naskah Pidato Presiden Soekarno, Jurnal Ilmiah : Fonema, Vol 4 No. 2, Bulan Desember, pp. 88-101.

[11] Https://www.youtube.com/watch?v=8ouLixXj8Eo (15/1/2019). Pidato Visi dan Misi Prabowo Subianto dan Sandiaga Uno "Indonesia Menang"

[12] Faisal, Abdul Jalil. 2008. Penggunaan Bahasa Indonesia Baku dalam Tesis Mahasiswa S2 
Universitas Hasanuddin, Linguistik Indonesia, Tahun ke 26, No. 1, Februari 2008 pp. 97-103.

[13] Chaer, Abdul. 2010. Kesantunan Berbahasa. Jakarta: Rineka Cipta.

[14] Arifin, Zaenal dan S. Amran Tasai. 2004. Cermat Berbahasa Indonesia. Jakarta: Akademika Pressindo.

[15] Alwi, Hasan, dkk. 1999. Tata Bahasa Baku Bahasa Indonesia. Jakarta: Balai Pustaka.

[16] Sumarsono, dan Paina Partana. 2002. Sosiolinguistik. Yogyakarta: Sabda dan Pustaka.

[17] Santoso, Kusno Budi. 1990. Problematika Bahasa Indonesia Praktis Bahasa Baku. Jakarta: Rineka Cipta

[18] Https://www.cnnindonesia.com>tag >livestreaming

[19] Mahsun. 2005. Metode Penelitian Bahasa. Jakarta: Raja Grafindo Persada

[20] Sudaryanto. 2015. Metode dan Teknik Analisis Bahasa. Yogyakarta: Sanata Dharma University Press.

[21] Sugono, Dendy dkk. 2008. Kamus Besar Bahasa Indonesia Edisi Keempat. Jakarta: PT Gramedia Pustaka Utama.

[22] Kosasih, E. dan Hermawan, Wawan. 2012. Bahasa Indonesia Berbasis Kepenulisan Karya Ilmiah dan Jurnal. Bandung: CV. Thursina

[23] Chaer, Abdul dan Leonie A. 1995. Sosiolinguistik: Perkenalan Awal. Jakarta: PT Rineka Cipta.

[24]Https://kemenperin.go.id/artikel〉deindustrialisasi>K embali>Intai>Indonesia

[25] Echols, John M. dan Hassan Shadily. 2000. Kamus Inggris Indonesia An English-Indonesia Dictionary. Jakarta : PT. Gramedia.

[26] Yuliana, Angellya Tri. 2013. Analisis Pemakaian Kata Serapan Dan Istilah Asing, dalam Artikel Opini Harian Kompas Edisi Mei-Juni 2012. eprints.ums.ac.id/23302/naskah_publikasi.pdf

[27] Darminto, dkk. 2010. Bausastra Jawa Kamus Jawa Besar. Surakarta: Kharisma.

[28] Waridah, Ernawati. 2012. Pedoman Kata Baku dan Tidak Baku Dilengkapi Ejaan Yang Disempurnakan. Jakarta: Ruang Kita

[29] Agustin, D. N. 2008. Diksi dan Gaya Bahasa dalam Pidato Soeharto. dalam Jurnal Penelitian Universitas Negeri Malang. 